Document downloaded from:

http://hdl.handle.net/10251/153693

This paper must be cited as:

De-Miguel-Molina, M.; Skinner, J. (2019). Walls of Expression and Dark Murals Tourism. Anthropology News. 60(6):3-6. https://doi.org/10.1111/AN.1310

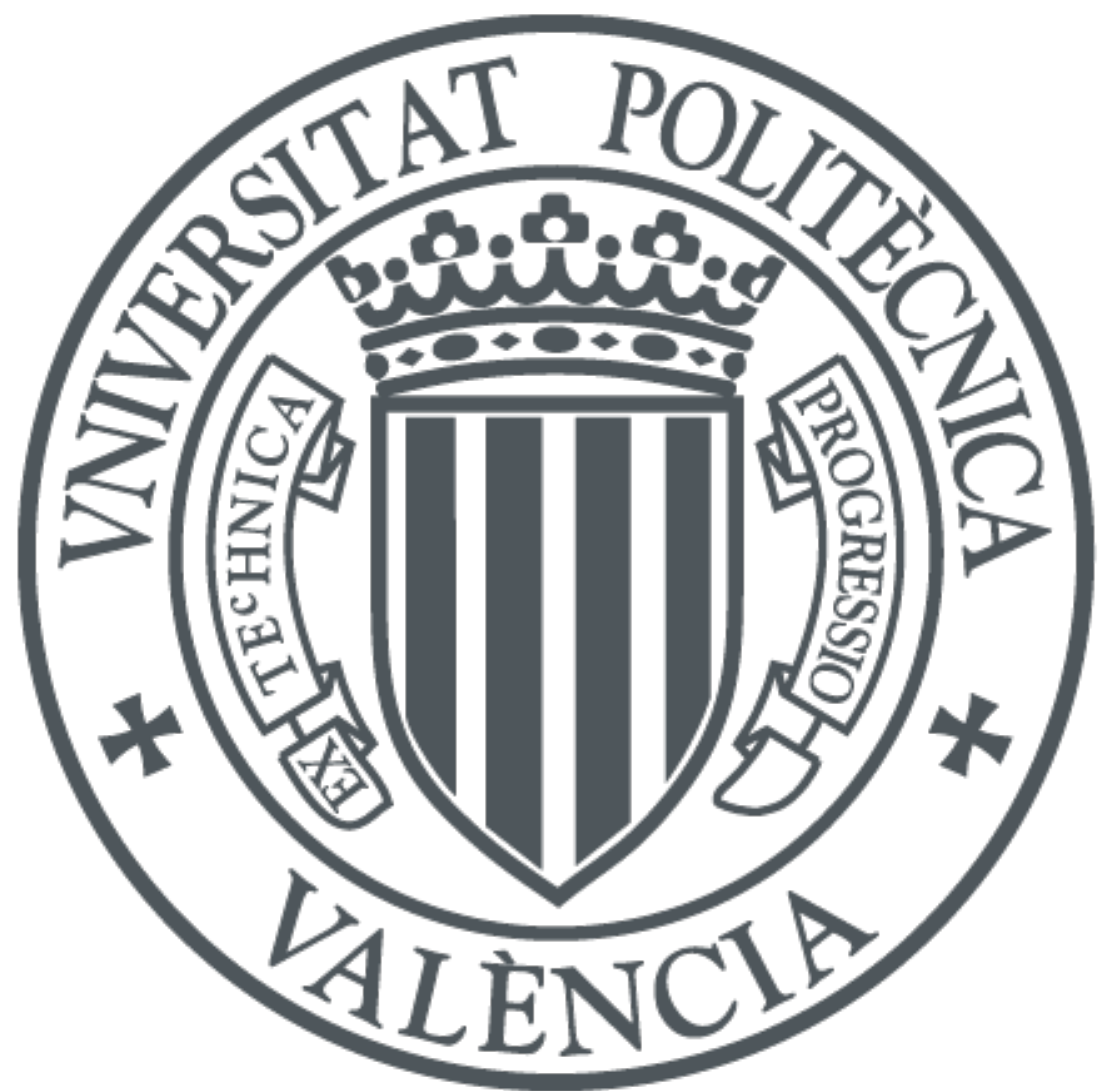

The final publication is available at

https://doi.org/10.1111/AN.1310

Copyright American Anthropological Association

Additional Information 


\section{Walls of Expression and Dark Murals Tourism}

\section{Walls}

María de Miguel Molina and Jonathan Skinner

November 15, 2019

\section{Notes on the Battle of Cable Street mural-a colorful depiction of the day anti-fascists faced down by Oswald Mosely's Blackshirts in London's East End.}

The west wall of the former St. George's town hall in London's East End is a giant vivid artwork. A riot of color to depict a protest turned violent public disorder: Blackshirts waving Union Jacks; people chanting from the barricades; milk bottles, tools, and fascist pamphlets flying through the air. Residents lean out of tenement windows. A man throws a punch at a policeman. A woman tips the contents of a chamber pot onto the marchers below. Mounted police maneuver horses, swing truncheons overhead. But, curiously, this mural is not seen as a symbol of violence, but as a symbol of solidarity and anti-fascism. Men, women, and children from different religions; immigrants from different nationalities; and even new faces fought together against a potential enemy.

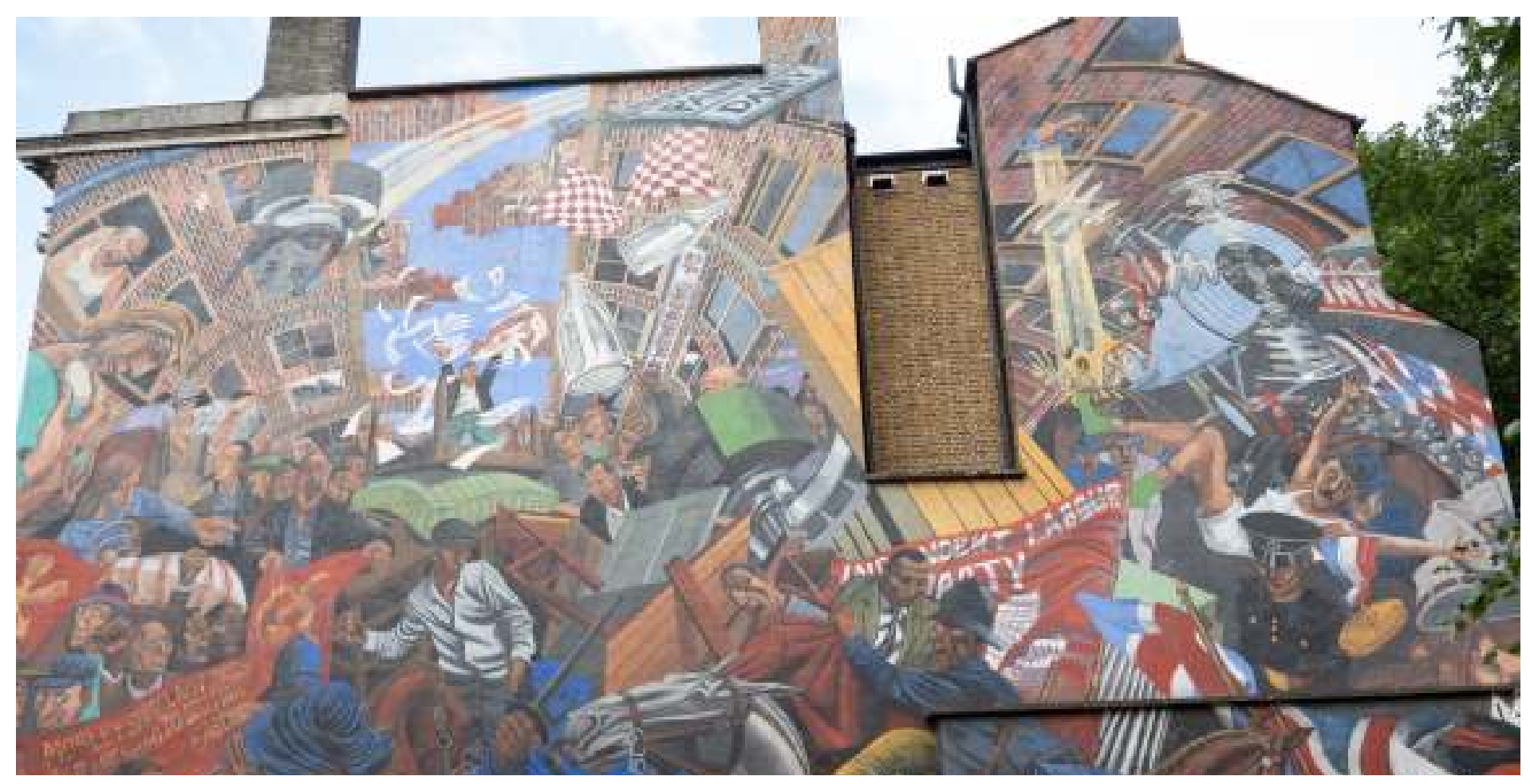




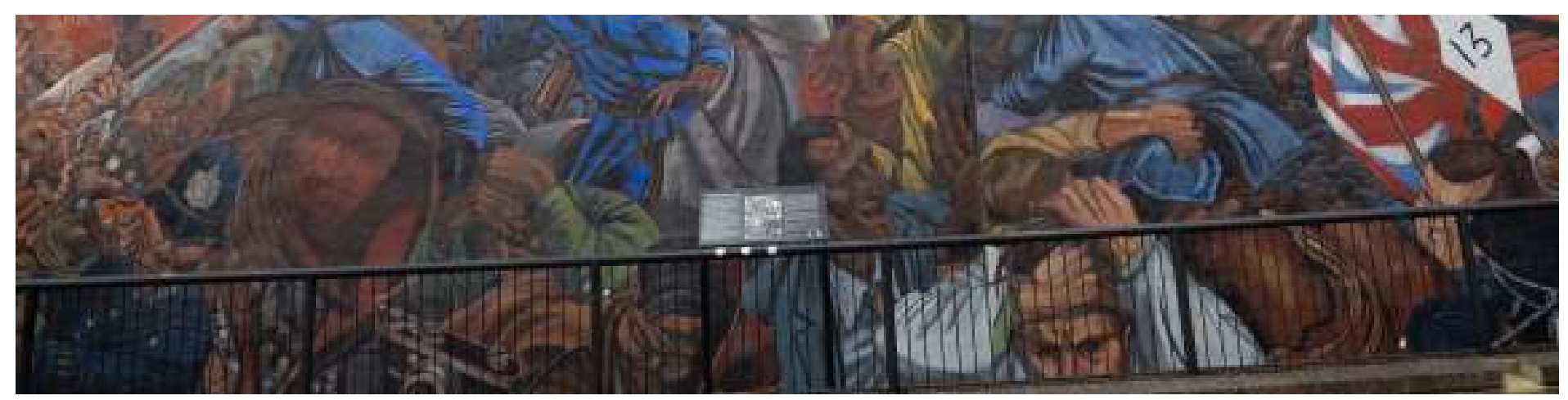

The Battle of Cable Street mural (image one). Carlos Ripoll, 2019

What is a mural to its public? How is public art placed, visited, and received? The writing on the wall reads "Mosley shall not pass," co-opting a popular slogan. A French military man used this expression against the German army during the First World War. A Republican woman used it against the Nationalists in the Spanish Civil War. And almost two months later, the neighbors of Cable Street used it against Mosley's Blackshirts. Many immigrants had moved to this East End of London looking for cheap housing, work at the factories, or just to escape from war: it was they who did not let Mosley pass through or separate them.

The Battle of Cable Street took place on October 4, 1936, when, in a febrile time of political unrest, anti-fascist demonstrators clashed with police deployed to protect a march by the British Union of Fascists led by Oswald Mosley. Hundreds were injured in the violent commotion between the protesting groups as well as between protestors and the police. It is a radical episode with contemporary relevance, invoked by politicians and anti-fascist organizations when making a stand or staging an anti-protest.

The first idea to paint a mural came from "the Basement Writers," a group of intellectuals established in 1973. The mural is more than a two-dimensional representation or open-air museum, more than public art on the side of a building. As visitors to and researchers of wall murals, we are interested in its content: the wall, its neighborhood, how it evolved, how it was kept, how it is shown. The mural is both tangible and intangible urban and conflict heritage. It is expressive; it is communicative; it tells a tale about people and place. It is a place where material and immaterial heritage go hand-in-hand. But you need to know what it wants to tell you, to identify with its message. You need to stop and observe every detail of the wall.

We interviewed David Rosenberg, a teacher, tour guide, writer, and descendent of Jewish immigrants to Whitechapel who is an authority on Cable Street history. He leads walking tours through the East End-pavement perambulations that take visitors "through radical times and places."

In the 1930s, along both sides of the street you would have shops at the ground level. My grandfather's cousin had a shop in number $27 . .$. The first two-thirds or three-quarters of 
the street was almost entirely Jewish and the last third/quarter was Irish. (Rosenberg)

The mural is both tangible and intangible urban and conflict heritage. It is expressive; it is communicative; it tells a tale about people and place. It is a place where material and immaterial go hand-in-hand.

The mural's painting is also a story of oppression and resistance in an era when Hitler's Nazis were gathering strength across Europe. In Spain, the civil war between Republicans and Franco's Nationalists-aided by Hitler and Mussolini-was galvanizing socialists and communists to join the fight against fascism. In Britain, Mosley's jackbooted British Union of Fascists was seeking to stir up anti-Jewish hatred among working-class Londoners. Mosley announced his forces would march through the East End.

The mixed community of East London (Jewish, Irish-Catholic, communists, and other groups) put up barricades to block the streets and force back the fascists' march. Police officers tried to facilitate the march but were forced to retreat and demand Mosely withdraw. The anti-protest prevailed.

The fascists tried to win the Irish against the Jews but, in the end, the Irish helped the Jewish. (Rosenberg)

Some of those who fought in the Battle of Cable Street, and had not been arrested, went to help the Republicans. Many of them died in Spain for their cause.

Almost 40 years later, from 1974 to 1984, efforts were made to commemorate the street battle in a huge mural wall. It was an opportunity to also add a more ethnically diverse group of faces to represent the area at the time of painting and to give the artwork contemporary relevance.

Nearly everything you see in the mural comes from oral histories from interviews... The idea of the mural came from the Basement Writers group, formed by 1973. (Rosenberg)

Four artists worked on it (designer Dave Binnington, Paul Butler, Ray Walker, and Desmond Rochford) narrating and expressing the battle in the social realist style of the Mexican muralists "Los Tres Grandes." The artists interviewed veterans to gather first-person accounts and the mural expresses the narrative of the event as it was experienced and recalled by those who participated. The mural was vandalized on several different occasions during its creation —daubed with racist slogans, spattered with paint bombs, its artists harassed-but it was touched up, restored, and completed. 
Fascist groups wrote graffiti and huge letters... Binnington already abandoned the work near the beginning because of the vandalism... Butler was threatened when he was doing restoration work on it in the early 1990s... Later they put a sort of varnish that protects the mural. (Rosenberg)

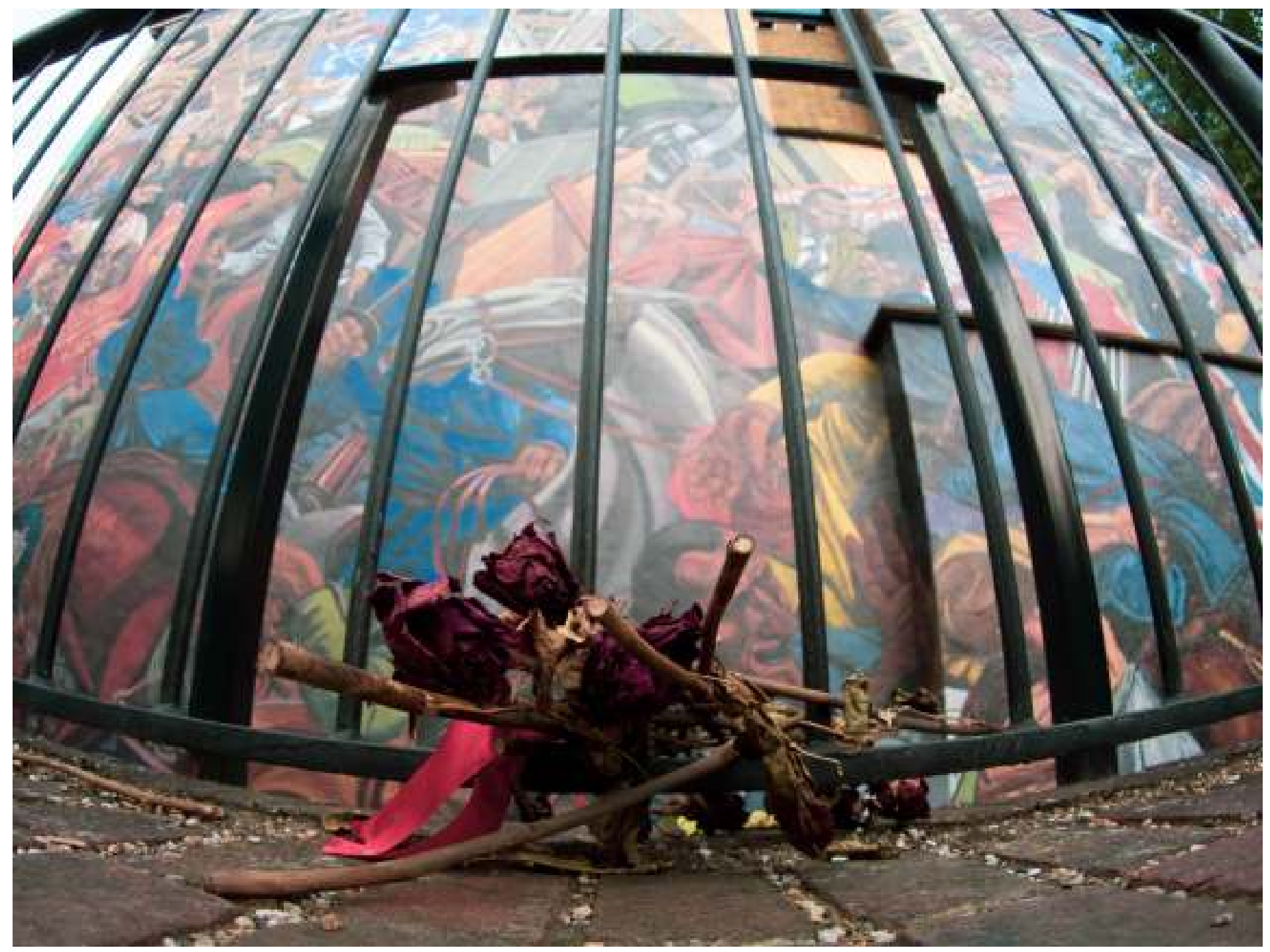

Flowers at the mural gate (image two). Carlos Ripoll, 2019

Every five or ten years the anniversary of the Battle of Cable Street is marked in some way. For the 80th anniversary in 2016, locals recorded their memories to capture and preserve an oral history of the episode. Rosenberg explained to us:

It has meaning to do this kind of event while the people who were part of it are still alive and could talk about it... Maybe we could produce an exhibition about antifascism clashes around the country... Also, the library organizes a book festival every year that could help memorialize it... The Council itself could organize tours.

In the 80th anniversary also a lot of Bengali and Irish came. The march started in Altab Ali Park, where a Bangladeshi young man was murdered in 1978 by a group of youths inspired 
by racists.

The population of the neighborhood has changed drastically since pre-World War II. By the 1970s, the area was home to a growing Bangladeshi community. Julian Cole, a journalist and owner of the Cable Street Inn, a historical and unusual guesthouse located just in front of the mural, has watched the area evolve over the last 23 years. Cole described the changes he has witnessed:

When I arrived here there were some Jewish shops... Gradually, all Jewish businesses disappeared... The next generation wanted to move to the southern... And, in the 1970s, the Bangladeshi immigrants started to came... This has been always an area of immigrants for 2,000 years.

With the holding of the 2012 London Olympics, the borough of Tower Hamlets became an international tourist destination. A bicycle route that crosses Cable Street was built in blue (sponsored by Barclays Bank). This is when Cole started his hospitality business:

The Council had a department for promoting tourism and they were very enthusiastic and supportive...to bring tourists from the Tower of London to the East End.

\section{To appreciate the history around a dark mural is one of the objectives of a reconstructive dark tourism, one that aims to revisit a dark event for educational purposes.}

So, why is the mural not promoted more? There are some successful examples of what we refer to as "dark murals tourism" - that is, visiting murals that show death, disaster, conflict, human tragedy. This would include murals that depict the history of a war or a controversial event: Unionist/Republican murals in Northern Ireland, the East Side Gallery in Berlin, the controversial Ataco murals of El Salvador, the "anti-enemies" murals of Teheran, and even Banksy's polemic artworks and the Walled Off Hotel in Palestine. This Cable Street mural certainly has a rich and dark history to show. And, despite ageing and eroding in color as well as viewers' affective engagement, it continues to attract people around it. It continues to have contemporary relevance. But, the local council does a poor job of promoting the mural, even if they are proud of it. Visitors typically come across it by chance, according to Cole

Visitors mostly don't know about the mural... But generally, people are quite interested on its history... We have also a certain amount of people from the Jewish diaspora coming from the USA and Israel who have family connections to East London. They visit where their ancestors lived... Other people are introduced to a different part of the city.

Some tours prefer to show tourists street art in the trendy and well-promoted Shoreditch 
neighborhood nearby. But Whitechapel, where Cable Street is located, has many histories to show and tell, including Jack the Ripper's haunts and crimes.

A lot of American people come here because they want history... There are also Irish traditional roots to this area...Besides Chinese tourists come in to explore the history of Chinese Opium market by the end of the nineteenth century and the places frequented by Oscar Wilde to smoke it... And other part, that to be honest I don't like, is the visit of this area where the famous gangsters, the Kray twins, operated by the 1950s and 1960s. (Cole)

$* \star \star$

The mural's neighbor, a woman walking her dog, does not stop. For her, the mural is part of the everyday landscape: she already knows it. The visitor stops, takes notice, and reads the information about the mural that is printed on a stand attached to the fence. Some visitors come to this site as a political pilgrimage. Others discover the mural by accident. With a fence to protect it from vandals and an information stand to inform visitors and passersby, the mural is being both framed and elevated as a site of pilgrimage (image two). This is site sacralization as the tourist attraction is made special for the visitor. Along the gate's handrail are the torn remains of anti-fascist stickers. They remind me of the murals along the Falls Road in Belfast with stickers on the lampposts in front of them. Some have candles or other three-dimensional displays that bring the murals out of the walls.

The area of bricks reminds us that behind the mural there is a working building (image one). The scene on the right shows Mosley dressed in a black uniform and military-style hat to mimic those of Hitler's Nazis. It is also Mosley with his little black moustache falling behind, now stripped of his uniform and in his undergarments.

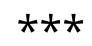

What will be the future of this neighbourhood in the next few years? Will this piece of art survive and what contemporary political relevance will it be given?

From a public policy perspective, more could be made of this contentious mural. It is part of British history leading up to World War II. Some action beyond anniversary rallies will be needed to conserve it.

What could affect the mural is what would happen with the building... I presume some social conservation will come around... the local community including the Bengals are very proud of the mural...But the most lively areas of the East End like Shoreditch are a long way from here... This area is not very touristic. (Rosenberg) 
Perhaps dark tourism will provide an answer. To appreciate the history around a dark mural is one of the objectives of a reconstructive dark tourism, one that aims to revisit a dark event for educational purposes.

When you observe the mural, you can interpret the violence underneath it, but also themes such as unity, solidarity, and integration. The Cable Street mural is a symbol against racism and racist actions. It can spark reflection on the current political moment; it can tell us something about how mixed we are and how we must avoid situations that foster fascism in the future. These themes can be harnessed to teach new generations as the mural becomes an interpretative canvas-an extra-mural classroom space, so to speak. It speaks to many and is diverse in its causes, its readings, and interpretations. The Cable Street mural can thus be a "wall of expression" (a wall emblazoned with meaning), a "wall of heritage," a "wall of pride," a "wall of empowerment," a "wall that speaks," a "peace wall" or simply a "political mural." But, above all, it is a community mural and we, as visitors, are lucky to share this open wall and reinterpret the history around it.

This project has received funding from the Valencian Regional Government, Spain, during the visiting research period of professor De Miguel Molina at the University of Roehampton. Reference: BEST/2019/175.

We would like to thank Julian Cole and David Rosenberg for their assistance and knowledge of the mural and its neighborhood.

María de Miguel Molina is a public policy specialist and associate professor at the Universitat Politècnica de València, Management Department. She has been a visiting scholar at the University of California, Berkeley and has published "Visiting African American Murals: a Content Analysis of Los Angeles, California," Journal of Tourism and Cultural Change (2019).

Jonathan Skinner is a reader in social anthropology at the University of Roehampton, Department of Life Sciences. He previously lectured at Abertay University, Dundee and Queen's University Belfast. He is co-editor of Visiting Murals: Politics, Heritage and Identity (2017).

Cite as: De Miguel Molina, María, and Jonathan Skinner. 2019. "Walls of Expression and Dark Murals Tourism." Anthropology News website, November 15, 2019. DOI: 10.1111/AN.1310

\section{Related Categories $\boldsymbol{+}$ \\ Related Tags $\boldsymbol{+}$}

